\title{
Mengenal NDMA dan NDEA, Dalang dibalik Penarikan Obat Antihipertensi ARB
}

\author{
Safira Anisa \\ Program Studi Sarjana Farmasi, Fakultas Farmasi, Universitas Padjadjaran, Sumedang 45363 \\ email: piasafira20@gmail.com \\ (Submit 28/1/2019, Revisi 14/7/2019, Diterima 15/7/2019)
}

\begin{abstract}
Abstrak
Pada Desember 2018 lalu, BPOM mengeluarkan penjelasan terhadap penarikan terhadap beberapa produk obat antihipertensi golongan angiotensin receptor blocker (ARB) seperti Irbesartan, Valsartan, dan Losartan di Indonesia. NNitrosodimethylamine (NDMA) dan N-Nitrosodiethylamine (NDEA) merupakan zat kimia organik yang termasuk golongan nitrosoamin. Nitrosamin merupakan senyawa dari bentuk kimia R1 NNOR 2. Dalam mini review ini selain dibahas mengenai profil NDMA dan NDEA, juga dibahas terkait alasan penarikannya beserta pertolongan pertama apabila mengkonsumsinya.
\end{abstract}

Kata kunci : NDMA, NDEA, antihipertensi, ARB

\section{Outline}

- Pendahuluan

- Alasan Penarikan Obat

- Mengenal NDMA dan NDEA

- NDMA

- NDEA

- Pertolongan Pertama

- Kesimpulan

- Daftar Pustaka

\section{Pendahuluan}

Pada Desember 2018 lalu, BPOM mengeluarkan penjelasan terhadap penarikan terhadap beberapa produk obat antihipertensi golongan angiotensin receptor blocker (ARB) seperti Irbesartan, Valsartan, dan Losartan di Indonesia.

\section{Alasan Penarikan Obat}

Alasan dibalik penarikan ini adalah karena ditemukannya suatu zat yang disebut $\mathrm{N}$ Nitrosodimethylamine (NDMA) dan N-Nitrosodiethylamine (NDEA) pada obat yang beredar. Berdasarkan penelusuran yang dilakukan oleh BPOM RI, kedua zat tersebut ditemukan pada bahan baku yang diimport dari salah satu perusahaan di Cina, yaitu Zhejiang Huahai Pharmaceuticals. 


\section{Mengenal NDMA dan NDEA}

NDMA dan NDEA merupakan zat kimia organik yang termasuk golongan nitrosoamin. Nitrosamin merupakan senyawa dari bentuk kimia R1 NNOR 2.

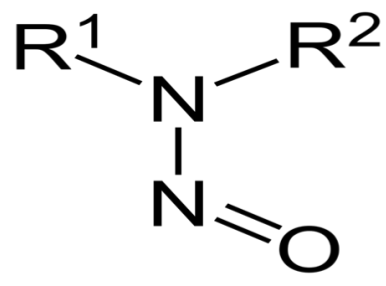

Gambar 1. Struktur kimia Senyawa Nitrosamin (Luan et al, 2005)

NMDA dan NDEA terbentuk melalui reaksi nitrit dengan amina sekunder. Sementara banyak nitrosamin bersifat karsinogenik, beberapa tidak, dan potensinya bervariasi tergantung pada struktur molekulnya.

$\mathrm{N}$-nitrosodimethylamine (NDMA), karsinogen yang sangat kuat, biasanya terdeteksi dan sering digunakan sebagai senyawa indikator untuk nitrosamin. Tingkat karsinogenisitas di antara senyawa-senyawa tersebut bervariasi. N-Nitrosodiethylamine (NDEA) adalah karsinogen yang paling kuat (Selin, 2011)

Beberapa contoh nitrosamin yang ditemukan pada makanan antara lain adalah NDMA (N-nitrosodimethyamine), NDEA (N-nitrosodiethylamine), NDBA (Nnitrosodibutylamine), NPIP (N-nitrosopiperidine), NPYR (N-nitrosopyrrolidine), NMOR (N-nitrosomorpholine), NDPhA (Nnitrosodiphenylamine), NPRO (N-nitrosoproline), dan NSAR (N- nitrososarcosine). Berdasarkan klasifikasi International Agency for Research on Cancer (IARC), NMDA dan NDEA merupakan nitrosoamin yang diklasifikasikan sebagai kelas $2 A$, yaitu probably carcinogenic to human. NMEA, NDBA, NPIP, NPYR, NMOR, and NSAR diklasifikasikan sebagai 2B (possibly carcinogenic to human), sedangkan NPRO dan $\mathrm{N}$ - nitrosodiphenylalnine (NDPhA) diklasifikan sebagai kelas 3 (not classifiable as to its carcinogenicity to humans) (Park, et al., 2015).

Sebuah penelitian yang dilakukan oleh Tanaka et al pada hamster yang berikan NDMA dan NDEA secara intratekal, menyimpulkan bahwa NDEA yang diberikan secara intratekal lebih berpotensi menyebabkan kanker pada sistem pernafasan dibandingkan dengan NDMA, Namun pemberian NDMA sendiri menyebabkan karsinogenik pada hati pada total dosis $1,5 \mathrm{mg}$ (Tanaka et al, 1988).

\section{NDMA}

NDMA atau Nitrosodimethylamine banyak digunakan terutama dalam penelitian laboratorium untuk menginduksi tumor pada hewan percobaan.

Zat ini dapat terbentuk selama memasak makanan, terutama daging dan ikan yang diawetkan, yang mengandung natrium nitrit sebagai pengawet, tetapi juga ditemukan dalam beberapa sayuran, keju, minuman beralkohol dan buah-buahan, dan sebagai kontaminan dalam produk karet. 
NMDA dapat muncul tiba-tiba dari berbagai bahan baku industri melalui beberapa reaksi kimia seperti yang melibatkan alkilamina dengan nitrogen oksida, asam nitrat atau garam nitrit. Sumber industri potensial termasuk produk sampingan dari penyamakan kulit, pabrik pestisida, pabrik karet dan ban, situs pembuatan dan penggunaan alkilamin, fasilitas pengolahan ikan, pabrik pengecoran dan pewarna. NDMA juga merupakan produk sampingan yang tidak disengaja dari klorinasi air limbah dan air minum di pabrik pengolahan yang menggunakan kloramin untuk desinfeksi (NCBI)

Paparan NDMA dapat terjadi melalui (EPA, 2014) :

- menelan makanan yang mengandung nitrosamin, seperti daging dan ikan yang diasap atau disembuhkan

- menelan makanan yang mengandung alkylamines, yang dapat menyebabkan NDMA terbentuk di perut

- minum air yang terkontaminasi

- minum minuman malt (seperti bir dan wiski) yang mungkin mengandung kadar nitrosamin rendah yang terbentuk selama pemrosesan

- menggunakan produk perlengkapan mandi dan kosmetik seperti sampo dan pembersih yang mengandung NDMA

- menghirup atau menghirup asap rokok. Paparan di tempat kerja dapat terjadi di penyamakan kulit, pabrik pembuat pestisida dan pabrik karet dan ban

Rute oral merupakan jalur utama paparan NDMA terhadap manusia (EPA, 2014). Paparan berlebih (overexposure) NDMA dapat menyebabkan kerusakan hati pada manusia. Gejala overexposure NDMA yang mungkin terjadi antara lain adalah sakit kepala, demam, mual, penyakit kuning, muntah, nyeri bagian perut, pembengkakan hati, penurunan fungsi hati, ginjal, dan paru-paru, serta pusing.

Dalam studi hewan dari berbagai spesies termasuk tikus dan tikus, paparan NDMA telah menyebabkan tumor terutama hati, saluran pernapasan, ginjal dan pembuluh darah (DHHS 2011; IARC 1998).

\section{NDEA}

NDEA atau N-Nitrosodiethylamine adalah minyak kuning terang yang sensitif terhadap cahaya, mudah menguap, dan larut dalam air, lipid, dan pelarut organik lainnya. NDEA biasa digunakan sebagai zat aditif pada bensin dan pelumas, antioksidan, dan stabilizer untuk bahan industri.

Ketika dipanaskan hingga terurai, NDEA mengeluarkan asap nitrogen oksida yang beracun. NDEA dapat mempengaruhi integritas DNA, mungkin dengan alkilasi, dan digunakan dalam penelitian eksperimental untuk menginduksi tumorigenesis hati. Itu dianggap cukup diantisipasi sebagai karsinogen manusia 


\section{Pertolongan Pertama}

Berikut pertolongan pertama yang dapat diberikan pada kecelakaan paparan NDMA dan NDEA

Mata : Pertama periksa korban, jika terdapat lensa kontak segera lepaskan. Bilas mata korban dengan air atau larutan garam normal selama 20 hingga 30 menit. Jangan mengoleskan salep, minyak, atau obat apa pun di mata korban tanpa instruksi khusus dari dokter. Segera bawa korban setelah mata memerah ke rumah sakit walaupun tidak ada gejala (seperti kemerahan atau iritasi) yang timbul.

Kulit: Segera alirkan air pada kulit yang terkena sambil melepas semua pakaian yang terkontaminasi. Cuci seluruh area kulit dengan hati-hati dengan sabun dan air.Segera hubungi rumah sakit atau pusat kendali racun walaupun tidak ada gejala (seperti kemerahan atau iritasi) yang berkembang.

Terhirup : Segera tinggalkan daerah yang terkontaminasi; ambil napas dalam-dalam dari udara segar. SEGERA panggil dokter dan bersiaplah untuk membawa korban ke rumah sakit walaupun tidak ada gejala (seperti mengi, batuk, sesak napas, atau terbakar di mulut, tenggorokan, atau dada). Berikan perlindungan pernapasan yang tepat untuk pelindung saat memasuki kondisi udara yang belum diketahui.

Tertelan: Jangan melakukan prosedur pemicu muntah. Jika korban sadar dan tidak kejang-kejang, berikan 1 atau 2 gelas air untuk mencairkan bahan kimia tersebut dan Segera hubungi rumah sakit atau pusat kendali racun. Jika korban kejang-kejang atau tidak sadarkan diri, jangan memberikan apa pun melalui mulut, pastikan jalan napas korban terbuka dan letakkan korban di sisinya dengan kepala lebih rendah dari badan.

Lainnya: Karena bahan kimia ini diketahui atau diduga sebagai karsinogen, Anda harus menghubungi dokter untuk meminta nasihat mengenai kemungkinan efek kesehatan jangka panjang dan rekomendasi potensial untuk pemantauan medis. Rekomendasi dari dokter akan tergantung pada senyawa spesifik, sifat kimia, fisik dan toksisitasnya, tingkat paparan, lama paparan, dan rute paparan. (NTP, 1992)

Adapun perihal pasien yang telah terlanjur mengonsumsi obat-obatan yang berpotensi mengandung NDEA atau NDMA disarankan untuk segera berkonsultasi dengan dokter atau apoteker yang terpercaya. Pasien yang terlanjur mengonsumsi obat tersebut dengan dosis yang lebih rendah atau untuk jangka waktu yang lebih pendek akan berisiko lebih rendah. Risiko juga akan lebih rendah untuk pasien yang menggunakan valsartan yang diproduksi oleh Zhejiang Tianyu, yang memiliki jumlah NDMA yang lebih kecil daripada valsartan yang diproduksi oleh Zhejiang Huahai.

BPOM menghimbau bagi pasien yang sudah terlanjur mengonsumsi obat antihipertensi yang berpotensi mengandung NDEA atau NDMA disarankan untuk segera berkonsultasi dengan dokter atau apoteker yang terpercaya. 


\section{Kesimpulan}

Penarikan oleh BPOM RI terhadap beberapa produk obat antihipertensi golongan angiotensin receptor blocker (ARB) seperti Irbesartan, Valsartan, dan Losartan di Indonesia perlu disikapi dengan bijak oleh masyarakat. Paparan NDEA dan NDMA berbahaya pada batas tertentu. Pertolongan pertama bagi pasien yang sudah terlanjur mengonsumsi obat antihipertensi yang berpotensi mengandung NDEA atau NDMA perlu dilakukan dan disarankan untuk segera berkonsultasi dengan dokter atau apoteker yang terpercaya.

\section{Daftar Pustaka}

BPOM. 2018. Penjelasan BPOM RI Tentang Penarikan Obat Antihipertensi Golongan Angiotensin Receptor Blocker. Tersedia di https://www.pom.go.id/new/view/more/klarifikasi/94/PENJELASAN-BPOM-RITENTANG-PENARIKAN-OBAT-ANTIHIPERTENSI-GOLONGAN-ANGIOTENSINRECEPTOR-BLOCKER.html

Environmental Protection Agency (EPA). 2014. Technical Fact Sheet - N-Nitrosodimethylamine (NDMA). Tersedia di : https://www.epa.gov/sites/production/files/201403/documents/ffrrofactsheet_contaminant_ndma_january2014_final.pdf

Luan, F., R. Zhang, C. Zhao, X. Yao, M. Liu, Z. Hu, and B. Fan .2005. Classification of the carcinogenicity of $\mathrm{N}$-nitroso compounds based on support vector machines and linear discriminant analysis, Chemical research in toxicology, 18(2), 198-203, doi:10.1021/tx049782q

National Center for Biotechnology Information. PubChem Compound Database; $\mathrm{CID}=6124$, https://pubchem.ncbi.nlm.nih.gov/compound/6124 (accessed Jan. 28, 2019).

National Center for Biotechnology Information. PubChem Compound Database; CID=5921, https://pubchem.ncbi.nlm.nih.gov/compound/5921 (accessed Jan. 28, 2019).

Park, J. E., Seo, J. E., Lee, J. Y., \& Kwon, H. (2015). Distribution of Seven NNitrosamines in Food. Toxicological research, 31(3), 279-88.

Selin, N.E. 2011. Environmental Guidelines and Regulations for Nitrosamines: A Policy Summary. Tersedia di http://www.tcmda.com/Global/Aminrapporter/MIT\%20nitrosamines\%20report\%20final.p df

Tanaka A., Hisanaga A., Inamasu T., Hirata M., Ishinishi N. (1988) . A comparison of the carcinogenicity of $\mathrm{N}$-nitrosodiethylamine and $\mathrm{N}$-nitrosodimethylamine after intratracheal instillation into Syrian golden hamsters. Food and Chemical Toxicology, 26 (10) , pp. 847- 850 